\title{
Purification of wastewater from cationic dye using SPGMA polymer: isotherm and kinetic study
}

\author{
Abu-Saied M.A. ${ }^{1}$ and Taha N.A. ${ }^{2 *}$ \\ 1Polymer Materials Research Department, Advanced Technology and New Materials, Research Institute, City for Scientific Research and \\ Technology Applications (SRTACITY), New Borg El-Arab City 21934, Alexandria, Egypt \\ 2Fabrication Technology Department, Advanced Technology and New Materials, Research Institute, City for Scientific Research and \\ Technology Applications (SRTACITY), New Borg El-Arab City 21934, Alexandria, Egypt \\ Received: 11/07/2019, Accepted: 26/03/2020, Available online: 01/06/2020 \\ *to whom all correspondence should be addressed: e-mail: nahlataha_1982@yahoo.com \\ https://doi.org/10.30955/gnj.003182
}

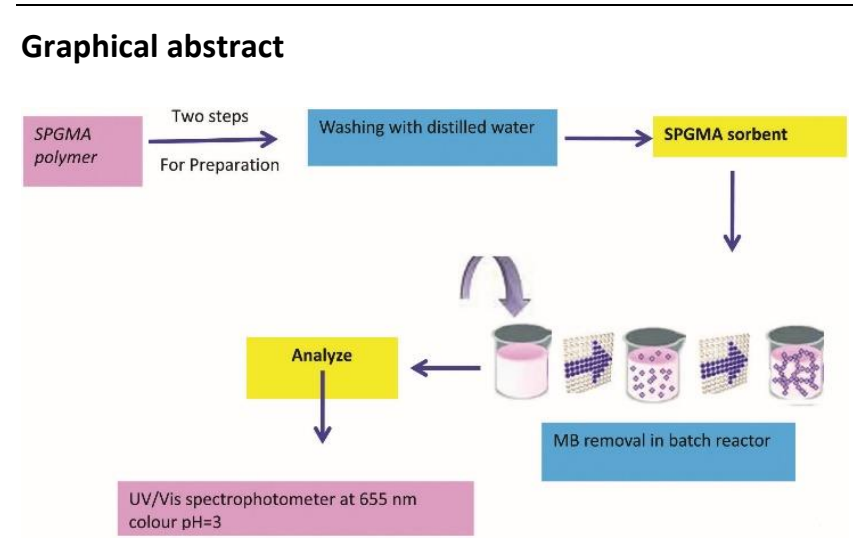

\begin{abstract}
One of the known methods for dye removing from wastewater is using sorbent material for fine removal of dye. The nano- cation exchanger Sulphonated poly glycidyl methacrylate (SPGMA polymer) was used as sorbent material for removing one of the common cationic dyes. SPGMA polymer was prepared and characterized to ensure its surface ability to sorb dye. Percentage removal of Methylene Blue using SPGMA polymer was studied by changing different parameters as sorbent amount, stirring speed, $\mathrm{pH}$ and solution temperature. The maximum value for dye removal was about $98 \%$. Adsorption data from experimental work shows that the results fit the pseudo first order model for all parameters studied except for $\mathrm{pH}$ study fits pseudo second order. Also, sorption mechanism for SPGMA polymer was studied for different dye concentration.
\end{abstract}

Keywords: Methylene blue, SPGMA, isotherm, kinetic, adsorption.

\section{Introduction}

One of cationic dyes is Methylene blue (MB) which used in various industries such as cotton, pulp, wool, paper, leather etc., to color their final products. The outlet of these industries containing huge amount of different dyes, discharged these types of dyes into waters drain, cause dangerous to the environment (Gad and El-Sayed, 2009). Acute exposure to MB dye will cause increased heart rate, shock, Heinz body formation, vomiting, cyanosis, jaundicem and quadriplegia (Hameed and Ahmad, 2009).

Various methods such as chemical, physical, and biological processes have been used trying to remove of cationic dyes from aquatic media (Barka et al., 2010; Bielska and Zymanowski, 2006; MohyEldin et al., 2016; Elahmadi et al., 2009; Karim et al., 2009; Khadhraoui et al., 2009; Lodha and Chaudhari, 2007). However, all the methods have some limitation and none of the processes described above were successful in removing color from wastewater completely. Dye removal process is the process calling Adsorption. Currently, most effective adsorbent is activated carbon. Which is high cost in production and regeneration these reasons make it uneconomical (Wang et al., 2005). Nowadays, there is an interest in using cheap and potential materials for the adsorption of reactive dyes. Several adsorbents were reported in the literatures such as clay (Tehrani-Bagha et al., 2011), zeolite (Han et al., 2009), fly ash (Rastogi et al., 2008), silica gel (Kushwaha et al., 2010) and chitosan (Mahmoodi et al., 2011) for the adsorption of basic dyes from aqueous solution.

In this work decolorize of Methylene blue dyes were studied using prepared polymer (SPGMA). To study the capability of color removal, different parameters that affect the adsorption process (such as time, $\mathrm{pH}$, and dosage of adsorbents, temperature and stirring speed) was studied. The kinetic models and equilibrium studies also carried out to substantiate the relationship with the experimental data for the adsorbent.

\section{Materials and methods}

\subsection{Preparation of methylene blue stock solution}

The cationic dye (MB dye) was from "NICE chemicals pvt. Itd company". The stock solution was prepared by dissolving $1.00 \mathrm{~g}$ of $\mathrm{MB}$ dye in $1000 \mathrm{~mL}$ distilled water. Diluting the prepared stock solution with distilled water to make Different concentrations for experiments. 


\subsection{Preparation of adsorbent material (SPGMA polymer)}

Sulphonated poly (glycidyl methacrylate) nano-cation exchanger (SPGMA) were prepared by two steps. First, general procedure for photo ATRP of GMA was as follows. To a $10 \mathrm{~mL}$ Schlenk tube containing $\mathrm{CuBr}_{2}$ and TPMA, evacuated and filled with argon. Argon-purged anisole was added under argon atmosphere. Sonicate the mixture in the Schlenk tube for $5 \mathrm{~min}$ to form a $\mathrm{CuBr}_{2}$ /TPMA complex. Subsequently GMA purged with argon and BPN was added to the Schlenk tube under argon atmosphere. The mixture was degassed by three freezepump-thaw cycles and backfilled with argon. Photo polymerization with light of $\lambda>350 \mathrm{~nm}$ was performed using a medium-pressure mercury lamp in a Spectromat apparatus (Ivoclar AG, Lichtenstein, glass filter $\lambda=350-550 \mathrm{~nm}$ ). To prevent heating of the sample during irradiation, the Schlenk tube was placed into a double-layer glass tube. In the outer layer of the finger, water thermo stated to $25^{\circ} \mathrm{C}$ was circulated. Second, the epoxy groups of PGMA chains were reacted with sodium sulphite (Elkady et al., 2011; Abu-Saied et al., 2013; MohyEldin et al., 2010; MohyEldin et al., 2011; Abu-Saied et al., 2017), dissolved in alcoholic aqueous solution at $80^{\circ} \mathrm{C}$ for $2 \mathrm{~h}$. Discharge the excess of sodium sulphite solution after centrifugation at $14,000 \mathrm{rpm}$ for $30 \mathrm{~min}$ using ultra speed centrifuge, distilled water used in washing to remove any un-reacted sodium sulphite. The details of the preparation and characterization of SPGMA polymer published before (AbuSaied et al., 2015)

\subsection{Experimental methods and measurements}

Batch adsorption technique was used in this work Put 100 $\mathrm{mL}$ of different dye concentration on rotary shaker, add different weighted adsorbent to the experimental flasks. Let solution to shake, different samples at different time intervals were taken out from the flasks and separated by decantation, then remaining $\mathrm{MB}$ dye concentration was analyzed using UV/Vis spectrophotometer at $655 \mathrm{~nm}$ (Ultrospec 2000 - Pharmacia Biotech). The effect of various important parameters in adsorption process as adsorbent dose, stirring speed, $\mathrm{pH}$ values and temperature was studied.

The equation used in calculating the amount of $M B$ dye adsorbed by SPGMA polymer was:

$$
\mathrm{q}=\left(\mathrm{C}_{0}-\mathrm{Ce}\right) * \mathrm{~V} / \mathrm{W}
$$

Where $\mathrm{q}(\mathrm{mg} / \mathrm{g})$ is the $\mathrm{MB}$ dye adsorbed by SPGMA polymer, $C_{0}$ and $\mathrm{Ce}(\mathrm{mg} / \mathrm{l})$ are the initial and equilibrium concentrations of the MB dye, respectively, $V(I)$, the initial volume of $\mathrm{MB}$ dye solution, and $\mathrm{W}(\mathrm{g})$, the weight of the polymer.

The percentage removal of $\mathrm{MB}$ dye from solution was by using the following equation:

$$
\% \operatorname{Re}=\left(C_{0}-C_{e}\right) / C_{0} * 100
$$

Where $\mathrm{C}_{0}$ and $\mathrm{Ce}(\mathrm{mg} / \mathrm{l})$ are the initial and equilibrium concentrations of the MB dye.

\section{Results and discussion}

\subsection{Effect of sorbent dose adsorption}

Figure 1 illustrates the adsorption removal from 20 ppm dye concentration. The percentage removal of dye was slightly increased with increasing SPGMA polymer dose from $0.025 \mathrm{~g}$ to $0.3 \mathrm{~g}$ along the total period of the experiment $(90 \mathrm{~min}$ ) to reach $98 \%$ for 0.2 and $0.3 \mathrm{~g}$ of sorbent material. This result concludes that more surface area was made due to increase of adsorbent mass. Therefore, the total number of active sites increases which increase the percentage removal of dye (Al-Qodah, 2000).

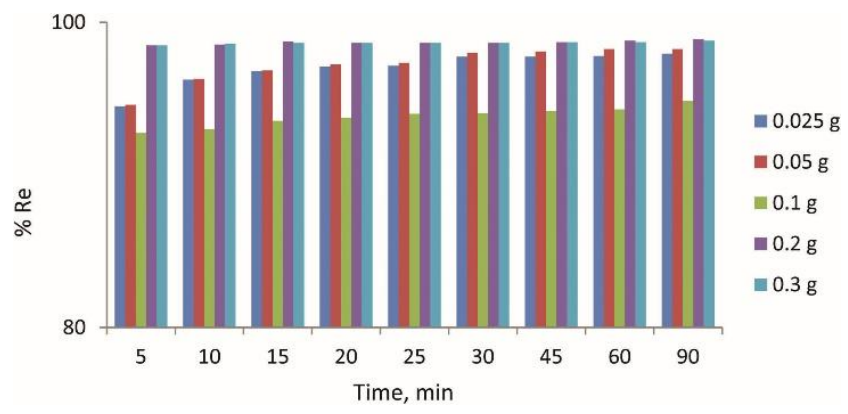

Figure 1. Effect of sorbent dose on adsorption of MB by SPGMA polymer (dye concentration: $20 \mathrm{mg} / \mathrm{l}$; stirring speed $200 \mathrm{rpm}$; contact time: $90 \mathrm{~min}$ )

\subsection{Effect of changing the stirring speed}

Figure 2 shows the adsorption removal by changing the stirring speed from $(100-500 \mathrm{rpm})$ at different time intervals from 5 to $90 \mathrm{~min}$. The figure concludes that the stroke speed affect slightly as the percentage removal decreased by incrasing stirring speed, and the highest percentage removal of dye was at $200 \mathrm{rpm}$.

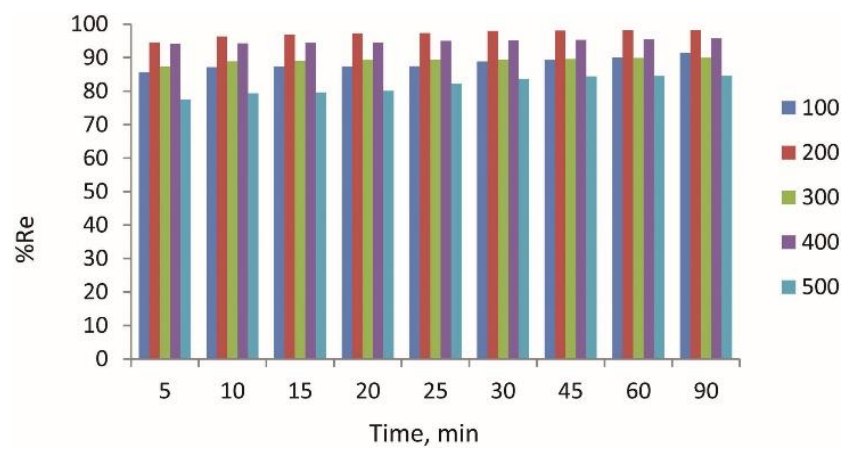

Figure 2. Effect of stirring speed on adsorption of MB by SPGMA polymer (dye concentration: $20 \mathrm{mg} /$; sorbent dose: $0.05 \mathrm{~g}$; contact time: $90 \mathrm{~min}$ )

\subsection{Effect of $\mathrm{pH}$ change}

Figure 3 shows adsorption capacity of MB dye by increasing $\mathrm{pH}$ value from 3 to 11 . The percentage removal of dye increase with increasing $\mathrm{pH}$ value to reach maximum value at $\mathrm{pH}=7$ which record about $98 \%$ dye removal, then decrease to reach the lowest value at $\mathrm{pH}=11$, so for future studies, the optimum $\mathrm{pH}$ adopted at $\mathrm{pH}$ 7. Also, the increasing time from 5 to $90 \mathrm{~min}$ for all $\mathrm{pH}$ values do not affect the removal percentage. 


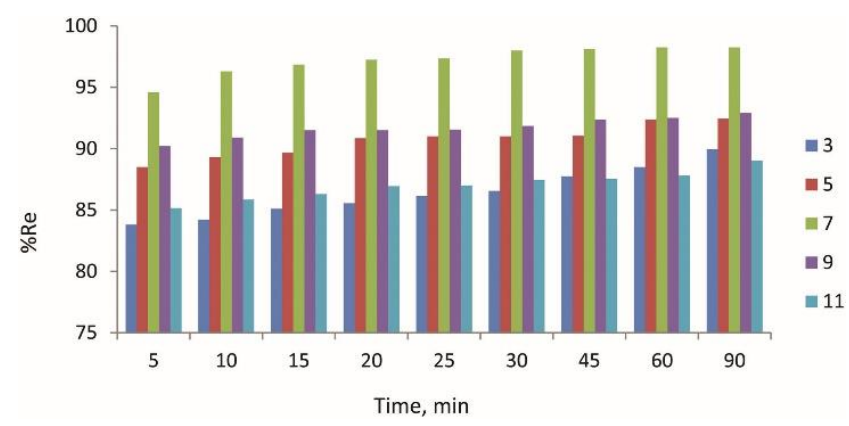

Figure 3. Effect of $\mathrm{pH}$ on adsorption of MB by SPGMA polymer (dye concentration: $20 \mathrm{mg} /$; stirring speed:200; sorbent dose: $0.05 \mathrm{~g}$; contact time: $90 \mathrm{~min}$ )

\subsection{Effect of temperature variation}

As illustrated in Figure 4, the decolonization of MB dye was tested for wide range of temperature from 20 to $35{ }^{\circ} \mathrm{C}$. The results cleared that by increasing the temperature of solution the percentage dye removal increased. To reach the maximum value at $25^{\circ} \mathrm{C}$. While by increasing time for each temperature, it does not have great effect. The temperature effect on adsorbtion process concludes in two major effects. Increasing the temperature is known to increase the rate of diffusion of the adsorbate molecules across the external boundary layer and in the internal pores of the adsorbent particles due to the decrease in the solution viscosity (Lagergren, 1898).

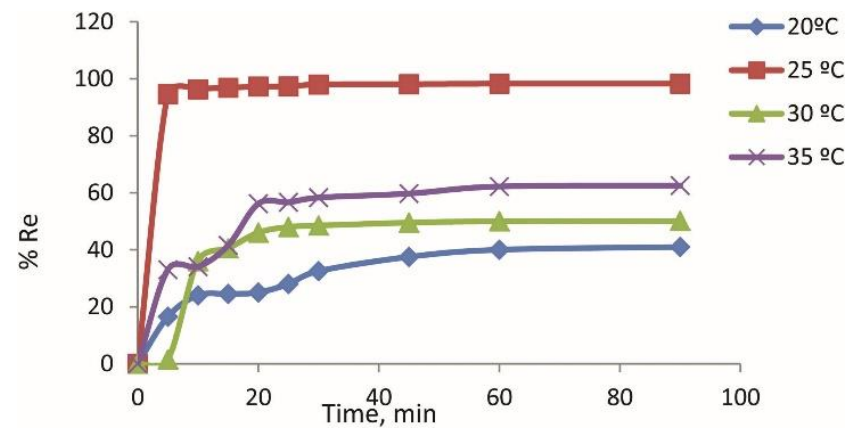

Figure 4. Effect of temperature on adsorption of MB by SPGMA polymer (dye concentration: $20 \mathrm{mg} / \mathrm{l}$; sorbent dose: $0.05 \mathrm{~g}$; stirring speed: $200 ; \mathrm{pH}: 7$; contact time: $90 \mathrm{~min}$ )

\section{Adsorption kinetics study}

The pseudo-first-order kinetic equation of Lagergren method for adsorption analysis (Ho and McKay, 1998):

$$
\frac{d q t}{d t}=k 1(q e-q t)
$$

By integrating equation ( 3 ) for boundary conditions as $t=0$ to $t=t$ and $q_{t}=0$ to $q_{t}=q_{t}$,

$$
\log (q e-q t)=\log \left[q e-\frac{k 1}{2.303} t\right.
$$

Where the equilibrium rate constant is $k_{1}(1 / \mathrm{min}), q_{\mathrm{e}}$ is the $\mathrm{MB}$ dye adsorbed on the surface at equilibrium ( $\mathrm{mg} / \mathrm{g}), q_{t}$ is the $\mathrm{MB}$ dye adsorbed at different times $(\mathrm{mg} / \mathrm{g})$. The adsorption rate constant $\left(k_{1}\right)$ for MB sorption by SPGMA polymer powder was determined from the figure which illustrates log $\left(q_{\mathrm{e}}-q_{t}\right)$ against time $t$ (as in Figure 5). The pseudo-first-order model at different parameters studied are summarized in Table 1.
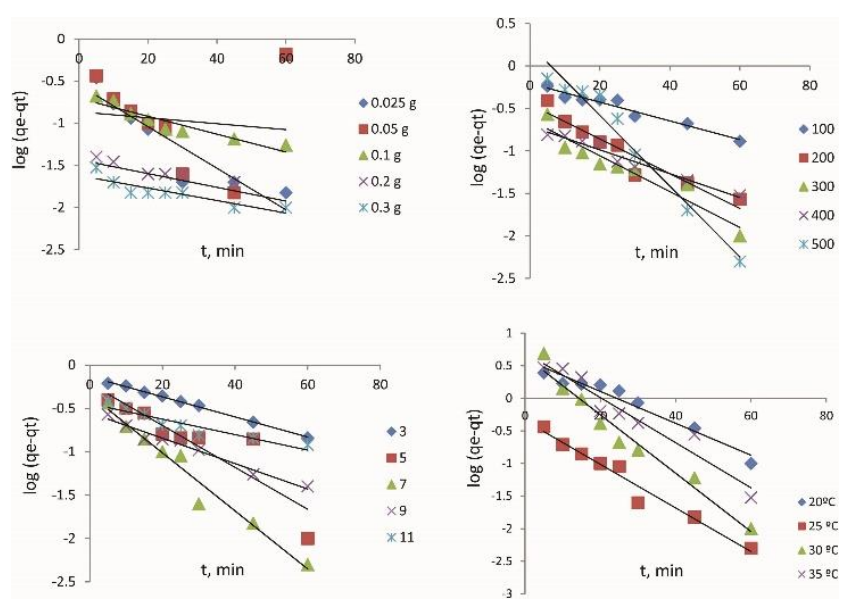

Figure 5. Pseudo-first-order kinetics for adsorption of $M B$ onto SPGMA polymer at different parameters

While equation (5) expressed pseudo-second-order kinetics (Ho and McKay, 2000; Weber and Morris, 1963):

$$
\frac{d q t}{d t}=k_{2}(q e-q t)^{2}
$$

As $k_{2}$ is the dye adsorption rate constant, $q_{\mathrm{e}}$ is the amount of $\mathrm{MB}$ dye adsorbed at equilibrium $(\mathrm{mg} / \mathrm{g}$ ) and $q t$ is the amount of $\mathrm{MB}$ dye adsorbed at different time intervals $t$ $(\mathrm{mg} / \mathrm{g})$. Separating the variables in Eq. (7) gives:

$$
\frac{d q t}{(q e-q t) 2}=k_{2} d t
$$

By Integrating equation (6) for the boundary conditions $t=0$ to $t=t$ and $q_{t}=0$ to $q_{t}=q_{t}$ :

$$
\frac{1}{q e-q t}=\frac{1}{q e}+k_{2} t
$$

by rearranging Eq. (7) the equation gives the following one:

$$
q t=\frac{\mathrm{t}}{\left(\frac{1}{k_{2} q e 2}\right)+\left(\frac{t}{q e}\right)}
$$

Which has a linear form of equation (9):

$$
\frac{t}{q t}=\frac{1}{k_{2} q e 2}+\frac{1}{q e} t
$$

As the equilibrium adsorption capacity $\left(q_{\mathrm{e}}\right)$, and second order constants $k_{2}(\mathrm{~g} / \mathrm{mg} \mathrm{min})$ can be determined experimentally from the slope and intercept of $t / q_{t}$ versus $t$ figure as in (Figure 6). 

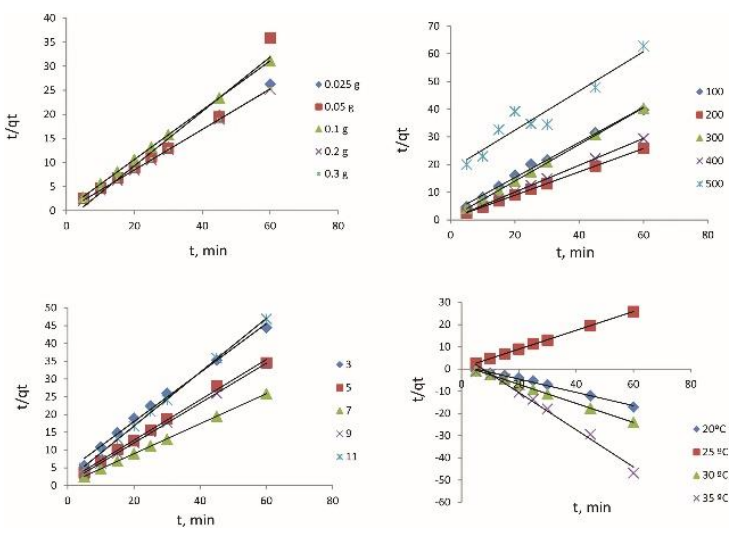

Figure 6. Pseudo-second-order kinetics for adsorption of $M B$ onto SPGMA polymer at different parameters

Table 1 present he coefficients of the pseudo-first- and second-order adsorption kinetic models. According to values of $R^{2}$ for the pseudo-first-order model and the $q$ values $\left(q_{e}\right.$, cal $)$ calculated for sorbent dose, stirring speed and temperature it seems fitted to it. While, the pseudo-second-order model better represented the adsorption kinetics, and this suggests for $\mathrm{pH}$ study. The overall rate of $\mathrm{MB}$ dye adsorption process appeared to be controlled by chemical process.

\section{Mechanism of sorption process}

In a solid-liquid adsorption process: the transfer of adsorbate is controlled either by boundary layer diffusion (called external mass transfer) or by intraparticle diffusion (called mass transfer through the pores), or by both processes. Generally accepted the adsorption dynamics consists of three consecutive steps: The first is the transport of adsorbate molecules from the bulk solution to the external surface of the adsorbent by diffusion through the liquid boundary layer, second is the diffusion from the external surface and into the pores of the adsorbent, finally, Adsorption on the active sites on the internal surface of the adsorbent pores.

The overall rate of adsorption is controlled by film or intraparticle diffusion, or by combination of both. The rate controlling step in systems characterized by dilute concentrations of adsorbate, poor mixing, and small particle size adsorbent is the boundary layer diffusion. Also, it has been cleared in many studies that boundary layer diffusion is dominant during the initial adsorbate uptake, then gradually adsorption rate becomes controlled by intraparticle diffusion after the adsorbent's external surface is loaded with the adsorbate.

Table 1. Comparison of the pseudo-first-order, pseudo-second-order adsorption rate constants and calculated and experimental $q_{\mathrm{e}}$ values obtained at different initial MB concentrations for different parameters studied

\begin{tabular}{|c|c|c|c|c|c|c|c|}
\hline \multirow[t]{2}{*}{ Dye system } & \multirow[t]{2}{*}{$q_{e, \exp ,} \mathrm{mg} / \mathrm{g}$} & \multicolumn{3}{|c|}{ Pseudo first order model } & \multicolumn{3}{|c|}{ Pseudo second order model } \\
\hline & & $\mathrm{K}_{1, \mathrm{~min}^{-1}}$ & $\mathrm{q}_{\mathrm{e} 1, \mathrm{mg} / \mathrm{g}}$ & $\mathbf{R}^{\mathbf{2}}$ & $\mathrm{K}_{2, \mathrm{~g} / \mathrm{mg} \cdot \mathrm{min}}$ & $\mathrm{q}_{\mathrm{e} 2, \mathrm{mg} / \mathrm{g}}$ & $\mathbf{R}^{2}$ \\
\hline \multicolumn{8}{|c|}{1 Sorbent dosage } \\
\hline \multicolumn{8}{|c|}{$\mathrm{n}=200 \mathrm{rpm}, \mathrm{C}_{0}=20 \mathrm{mg} / \mathrm{l}$} \\
\hline$w=0.025 \mathrm{~g}$ & 0.41 & 0.0567 & 0.283 & 0.847 & 13.35 & 5.378 & 1 \\
\hline$w=0.05 \mathrm{~g}$ & 0.35 & 0.0081 & 0.1366 & 0.814 & -1.57 & 3.133 & 0.949 \\
\hline $\mathrm{w}=0.1 \mathrm{~g}$ & 1.03 & 0.0244 & 0.8968 & 0.879 & 10.36 & 3.807 & 1 \\
\hline $\mathrm{w}=0.2 \mathrm{~g}$ & 0.22 & 0.0189 & 0.0368 & 0.603 & 122.39 & 5.666 & 1 \\
\hline $\mathrm{w}=0.3 \mathrm{~g}$ & 0.24 & 0.0170 & 0.0239 & 0.781 & 234 & 5.626 & 1 \\
\hline \multicolumn{8}{|c|}{ 2-rpm } \\
\hline \multicolumn{8}{|c|}{$\mathrm{W}=0.05 \mathrm{~g}, \mathrm{pH}=7, \mathrm{CO}=20 \mathrm{mg} / \mathrm{l}$} \\
\hline $\mathrm{rpm}=100$ & 1.72 & 0.0253 & 1.222 & 0.949 & 0.155 & 1.5745 & 0.9939 \\
\hline $\mathrm{rpm}=200$ & 0.35 & 0.0469 & 0.3549 & 0.922 & 0.354 & 2.3702 & 0.9999 \\
\hline $\mathrm{rpm}=300$ & 2 & 0.0486 & 1.832 & 0.911 & 0.579 & 1.5087 & 0.9998 \\
\hline $\mathrm{rpm}=400$ & 0.85 & 0.0322 & 0.696 & 0.962 & 0.612 & 2.066 & 0.9998 \\
\hline $\mathrm{rpm}=500$ & 3.08 & 0.0958 & 2.779 & 0.965 & 0.029 & 1.4098 & 0.9196 \\
\hline \multicolumn{8}{|c|}{ 3-pH } \\
\hline \multicolumn{8}{|c|}{$W=0.05 \mathrm{~g}, \mathrm{rpm}=200, \mathrm{CO}=20 \mathrm{mg} / \mathrm{l}$} \\
\hline $\mathrm{pH}=3$ & 2.01 & 0.0267 & 0.735 & 0.9973 & 0.1138 & 1.449 & 0.9927 \\
\hline $\mathrm{pH}=5$ & 1.51 & 0.0557 & 0.611 & 0.8035 & 0.2314 & 1.759 & 0.9968 \\
\hline $\mathrm{pH}=7$ & 0.35 & 0.0772 & 0.453 & 0.9665 & 0.366 & 0.366 & 0.999 \\
\hline $\mathrm{pH}=9$ & 1.42 & 0.0338 & 0.282 & 0.9698 & 0.424 & 1.779 & 0.9996 \\
\hline $\mathrm{pH}=11$ & 2.2 & 0.0205 & 0.358 & 0.8839 & 0.365 & 1.3989 & 0.9996 \\
\hline \multicolumn{8}{|c|}{ 4-Tempreture } \\
\hline \multicolumn{8}{|c|}{$\mathrm{W}=0.05 \mathrm{~g}, \mathrm{rpm}=200, \mathrm{CO}=20 \mathrm{mg} / \mathrm{l}$} \\
\hline $\mathrm{T}=20$ & 4.8 & 0.0564 & 3.628 & 0.9524 & 0.062 & 3.339 & 0.9896 \\
\hline$T=25$ & 0.35 & 0.0772 & 0.453 & 0.9665 & 0.366 & 2.365 & 0.999 \\
\hline$T=30$ & 9.98 & 0.1032 & 8.392 & 0.9665 & 0.11 & 2.332 & 0.9994 \\
\hline$T=35$ & 7.5 & 0.0797 & 5.062 & 0.936 & 0.113 & 1.192 & 0.9834 \\
\hline
\end{tabular}


Equation (10) present intraparticle diffusion parameter, $k_{i}(\mathrm{mg} / \mathrm{g} \min 0.5)$ (Ho and McKay, 1998):

$$
q=k_{i} t^{0.5}+c
$$

as $q$ is the MB dye adsorbed (mg/g) at time $t$, while $k_{i}$ is intraparticle diffusion constant ( $\mathrm{mg} / \mathrm{g} \mathrm{min})$, and $c$ is the intercept. It can be calculated from the slope of the linear plot of $q_{t}$ versus $t^{1 / 2}$. The slope of the curve of different initial concentrations shows the $k_{\text {id }}$ values as shown in Table 2. Theoretically, the graph of $k_{i}$ versus $t^{0.5}$ should separate at least to four linear regions that represent boundary layer diffusion, followed by intraparticle diffusion in macro, meso, and micro pores. These four regions are followed by a horizontal line representing the system at equilibrium. Also, the figure of dye uptake, illustrate $q_{t}$ versus square root of time $\left(t^{1 / 2}\right)$ should be linear if intraparticle diffusion is involved in dye adsorption process and if these lines pass through the origin point, intraparticle diffusion is the rate controlling step. If the lines do not pass through the origin point, this indicates some degree of boundary layer control and this further shows that the intraparticle diffusion is not the only ratelimiting step. The boundary layer thickness can be indicated by the intercept value as the intercept increase, the greater the boundary layer effect.

Table 2. Intraparticle diffusion constants for different initial MB concentrations

\begin{tabular}{|c|c|c|c|}
\hline Initial concentration (mg/L) & $k_{\text {id }}\left(\mathrm{mg} / \mathrm{g} \mathrm{min}^{1 / 2}\right)$ & $C$ & $R^{2}$ \\
\hline 5 & 0.0483 & 1.8282 & 0.9303 \\
\hline 10 & 0.0195 & 1.8679 & 0.8432 \\
\hline 15 & 0.0291 & 1.8025 & 0.8335 \\
\hline 20 & 0.0272 & 1.7375 & 0.9127 \\
\hline 25 & 0.1687 & 0.3519 & 0.8149 \\
\hline
\end{tabular}

\section{Conclusions}

The present results in this study show that the SPGMA polymer has high ability to adsorb methylene blue dye from wastewater with removal percentage about $98 \%$ and more. Different parameters are studied, and Adsorption kinetics was studied. Comparing q calculated and q experimental shows that the results follows pseudo first order for sorbent dose, rpm and temperature while fitted pseudo second order for $\mathrm{pH}$. Also, the results clear that the overall MB dye adsorption rate controlled by chemical process. This research concludes the ability of SPGMA polymer in removal of cationic dye with high removal efficiency.

\section{References}

Abu-Saied M.A., Fontananova E., Drioli E. and Eldin M.S.M. (2013), Sulphonated poly (glycidyl methacrylate) grafted cellophane membranes: novel application in polyelectrolyte membrane fuel cell (PEMFC), Journal of Polymer Research, 20(7), 187.

Abu-Saied M.A., RyszardWycisk, Moustafa, Abbassy M., Abd ElNaim G., El-Demerdash F., Youssef M.E., Bassuony H. and Peter N.P. (2017), Sulfated chitosan/PVA absorbent membrane for removal of copper and nickel ions from aqueous solutions-Fabrication and sorption studie, Carbohydrate Polymers, 165, 149-158.

Abu-Saied M.A., Taha T.H., Taha N.A., Elsayed Youssef M. and ChmelaŠtefan (2015), Removal of Cationic Reactive Dye Using SPGMA Combined with an Isolated Bacterial Strain, Advances in Environmental Biology, 9 (24), 466-481.

Al-Qodah Z. (2000), Adsorption of dyes using shale oil ash, Water Research, 34(17), 4295-4303.

Barka N., Qourzal S., Assabbane A., Nounah A. and Ait-Ichou Y. (2010), Photocatalytic degradation of an azo reactive dye, Reactive Yellow 84, in water using an industrial titanium dioxide coated media, Arabian Journal of Chemistry, 3, 279283.
Bielska M. and Szymanowski J. (2006), Removal of methylene blue from wastewater using micellar enhanced ultrafiltration, Water Research, 40, 1027-1033.

Elahmadi M.F., Bensalah N. and Gadri A. (2009), Treatment of aqueous wastes contaminated with Congo Red dye by electrochemical oxidation and ozonation processes, Journal of Hazardous Materials, 168, 1163-1169.

Elkady M.F., Abu-Saied M.A., Rahman A.M.A., Soliman E.A. and Elzatahry A.A. (2011), Nano-sulphonated poly (glycidyl methacrylate) cations exchanger for cadmium ions removal: effects of operating parameters, Desalination, 279(1-3), 152-162.

Gad H.M.H. and El-Sayed A.A. (2009), Activated carbon from agricultural by-products for the removal of Rhodamine-B from aqueous solution, Journal of Hazardous Materials, 168, 1070-1081.

Hameed B.H. and Ahmad A.A. (2009), Batch adsorption of methylene blue from aqueous solution by garlic peel, an agricultural waste biomass Journal of Hazardous Materials, 164, 870-875.

Han R., Zhang J., Han P., Wang Y., Zhao Z. and Tang M. (2009), Study of equilibrium, kinetic and thermodynamic parameters about methylene blue adsorption onto natural zeolite, Chemical Engineering Journal, 145, 496-504.

Ho Y.S. and McKay G. (1998), Sorption of dye from aqueous solution by peat, Chemical Engineering Journal, 70(2), 115-124.

Ho Y.S. and McKay G. (2000), The kinetics of sorption of divalent metal ions onto sphagnum moss peat, Water Research, 34 (3), 735-742.

Ho Y.S. and McKay G. (1998), The kinetics of sorption of basic dyes from aqueous solution by sphagnum moss peat, The Canadian Journal of Chemical Engineering, 76, 822-827.

Karim A.B., Mounir B., Hachkar M., Bakasse M. and Yaacoubi A. (2009), Removal of Basic Red 46 dye from aqueous solution by adsorption onto Moroccan clay, Journal of Hazardous Materials, 168, 304-309. 
Khadhraoui M., Trabelsi, Ksibi H.M., Bouguerra S. and Elleuch B. (2009), Discoloration and detoxicification of a Congo red dye solution by means of ozone treatment for a possible water reuse, Journal of Hazardous Materials, 161, 974-981

Kushwaha A.K., Gupta N. and Chattopadhyaya M.C. (2010), Enhanced adsorption of malachite green dye on chemically modified silica gel, Journal of Chemical and Pharmaceutical Research, 2(6), 34-45.

Lagergren S. (1898), About the theory of so-called adsorption of soluble substances, Kungliga Svenska Vetenskapsa kademiens Handlingar, 24(4), 1-39.

Lodha B. and Chaudhari S. (2007), Optimization of Fentonbiological treatment scheme for the treatment of aqueous dye solutions, Journal of Hazardous Materials, 148, 459-466.

Mahmoodi N.M., Salehi R., Arami M. and Bahrami H. (2011), Dye removal from colored textile wastewater using chitosan in binary systems, Desalination, 267, 64-72.

MohyEldin M.S., Elkady M.F., Abu-Saied M.A., Abdel Rahman A.M., Soliman E.A., Elzatahry A.A. and Youssef M.E. (2010), Removal of cadmium ions from synthetic aqueous solutions using a novel nano-sulphonated poly Glycidyl methacrylate cation exchanger: Kinetic and equilibrium studie, Journal of Applied Polymer Science, 118( 6), 3111-3122.

MohyEldin M.S., Elzatahry A.A., El-Khatib K.M., Hassan E.A., ElSabbah M.M. and Abu-Saied M.A. (2011), Novel Grafted Nafion Membranes for Proton Exchange Membrane Fuel Cell (PEMFC) Applications, Journal of Applied Polymer Science, 119, 1, 120-133.

MohyEldin M.S., Gouda M.H., Abu-Saied M.A., El-Shazly Y.M.S. and Farag H.A. (2016), Development of grafted cotton fabrics ions exchanger for dye removal applications: methylene blue model, Desalination and Water Treatment, 57, 22049-22060.

Rastogi K., Sahu J.N., Meikap B.C. and Biswas M.N. (2008), Removal of methylene blue from wastewater using fly ash as an adsorbent by hydrocyclone, Journal of Hazardous Materials, 158, 531-540.

Tehrani-Bagha A.R., Nikkar H., Mahmoodi N.M., Markazi M. and Menger F.M. (2011), The sorption of cationic dyes onto kaolin: kinetic, isotherm and thermodynamic studies, Desalination, 266, 274-280.

Wang S.B., Boyjoo Y., Choueib A. and Zhu Z.H. (2005), Removal of dye from aqueous solution using fly ash and red mud, Water Research, 39, 129-138.

Weber W.J. Jr. and Morris J.C. (1963), Kinetics of adsorption on carbon from solution, Journal of the Sanitary Engineering Division Proceedings American Society of Civil Engineers, 89, 31-59.

Yeddou N. and Bensmaili A. (2005), Kinetic models for the sorption of dye from aqueous solution by clay-wood saw dust mixture, Desalination, 185, 499-508. 